\title{
THE AUDITORS' REPORT
}

To the Council and Members of the

Fauna Preservation Society.

23rd February, 1962.

ACCOUNTS For THE YeAR ENDED 31sT DeCEMBER, 1961

We have completed the audit of the Books and Accounts of the Society for the year ended 31st December, 1961, and report thereon as follows :-

\section{General Purposes Account}

The Balance on this Account at the end of the year was $£ 2,27516 s .7 d$. after transferring $£ 95$ from the Life Membership Fund, $£ 676$ 10s. profit on sale of Investments, and deducting $£ 1,44015 s$. $5 d$., being the excess of Expenditure over Income on the year's working.

The excess of Expenditure over Income in the previous year was $£ 902$ 10s. 4 d.

\section{GENERAL ReSERVE Fund}

The Balance on this Fund at the 1st January, 1961, was $£ 9,9742$ s., to which has been added $£ 6270$ s. $4 d$. in respect of Donations and Legacy transferred from Income and Expenditure Account.

The Expenditure charged to the Fund during the year includes $£ 2,861 \mathrm{ls}$. 3d. for the African Special Project and a donation of $£ 500$ to the Kenya Water for Wild Animals Fund.

At 31st December, 1961, the Balance on the Fund was $£ 7,240$ 1s. 1 d.

Number of MEMbers and ARREARS OF SubSCRIPTIONS

The number of Members on the Roll at 31st December, 1961, was 2,146, made up as follows:-

\begin{tabular}{llr} 
Honorary Members : & 24 \\
Life Members & $:$ & 435 \\
Ordinary Members : & $:$ & 1,687 \\
\hline 2,146
\end{tabular}

This shows an increase of 9 Honorary Members, 48 Life Members and 177 Ordinary Members.

At 31st December, 1961, there were 87 Members in arrear with their subscriptions.

\section{LIFE MEMBERSHIP FuND}

The balance standing to the credit of the Fund is now $£ 5,835$. This is after crediting $£ 890$ in respect of Life Membership subscriptions received during the year and transferring $£ 95$ to the General Purposes Account which represents the value of subscriptions of those Life Members whose membership ceased during the year. 
INVESTMENTS

The total investments at 31st December, 1961, at Cost amounted to $£ 15,15618$ s. $8 d$., and the Market Value at that date was $£ 15,51716$ s. $4 d$., showing a net appreciation of $£_{360} 17 s$. 8d. During the year certain investments were realized showing a profit of $£ 67610$ s.

\section{SURPLUS}

The surplus of Assets over Liabilities at the end of the year amounted to $£ 15,350$ 17s. $8 d$., as compared with $£ 17,9594 s$. at the end of the previous year.

\section{"Operation Noah" \\ Kariba Fund}

We have examined the transactions relating to this Fund, and annexed to the Society's Accounts is the Receipts and Payments Account for the year to 31st December, 1961, from which it will be seen that further donations totalling $f_{191} 19$ s. $11 \mathrm{~d}$. have been received.

A payment of $£ 1,000$ to the Game Preservation and Hunting Association of Northern Rhodesia, and sundry expenses of $£ 124 \mathrm{~s}$. 4d. have been made during the year, leaving a cash balance in hand of $£ 3876$ s.

\section{"Operation ORYX"}

We have examined the transactions relating to this Fund which was opened in July and donations amounting to $£ 3,1022 s$. have been received. A single payment of $£ 1,000$ has been made to Major Ian Grimwood, leader of the Operations, leaving a balance in hand of $£ 2,1022 s$.

$$
\begin{aligned}
& \text { (Signed) W. B. KEEN \& Co., } \\
& \text { Chartered Accountants. }
\end{aligned}
$$




\section{"Operation Noah"-Kariba Fund \\ RECEIPTS AND PAYMENTS ACCOUNT}

For the YeAR to 31ST DeCEMBER, 1961

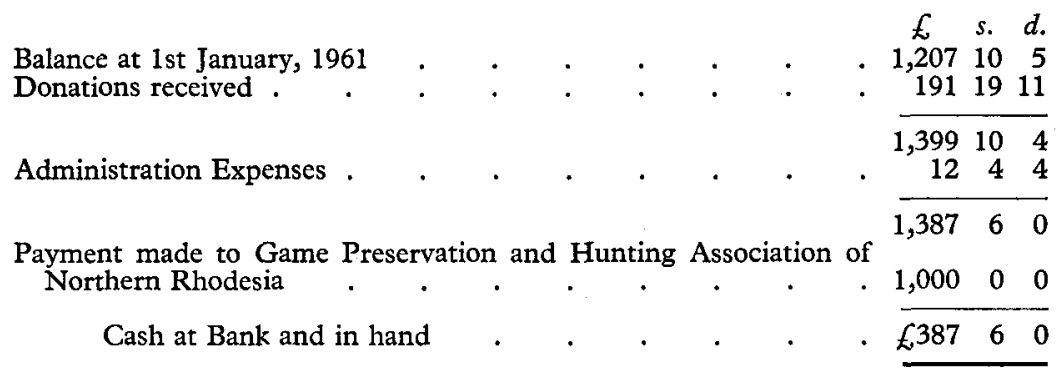

We have examined the above Receipts and Payments Account with the books and accounts of the Fund, and certify it to be in accordance therewith.

We have verified the Cash balance.

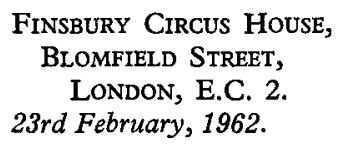

W. B. KEEN \& CO., Chartered Accountants. 
GENERAL PURPOSES

1960.

EXPENDITURE

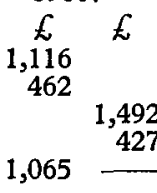

149

126

136

180

78

298

17

100

289

68

26$$
\text { s) }
$$

dvertising

, Postage, etc.

Films-Purchases

"Films-Maintenance

"Assistant Secretary's PensionPremium

"Secretary's Travelling Expenses

"Accountancy and Audit-

Audit Fee, 1961

Accountancy, 1961.

Income Tax Claim, 1961

, Subscriptions and Donations-

British Committee for International Nature Conserva-

International Council for Bird Preservation. Council for Nature

, “ Huxley in Africa " Pamphlet -Net

President's 'and 'Secretary's visits to I.U.C.N.-Switzerland

,African Special Project

Less Donations received . $\quad 750 \quad 0 \quad 0$

, Kenya-Water for Wild Animals-

Donation .

Less Transferred to General Reserve Fund

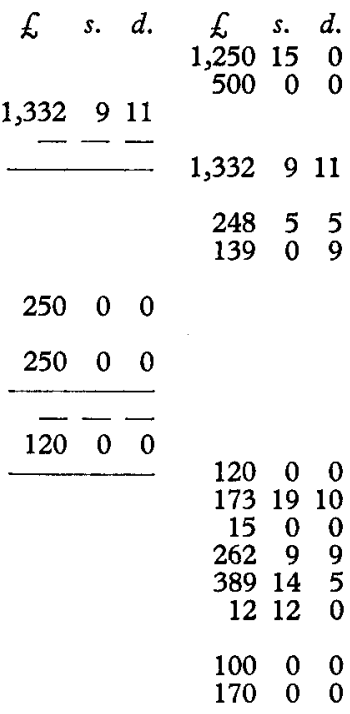

$\begin{array}{lll}21 & 0 & 0\end{array}$

$\begin{array}{lll}31 & 10 & 0\end{array}$

$\begin{array}{lll}26 & 5 & 0\end{array}$

$\begin{array}{lll}78 & 15 & 0\end{array}$

$$
\begin{array}{rrr}
20 & 0 & 0 \\
5 & 5 & 0 \\
1 & 0 & 0
\end{array}
$$

$\begin{array}{lll}146 & 3 & 4\end{array}$

105138 


\section{ACCOUNT}

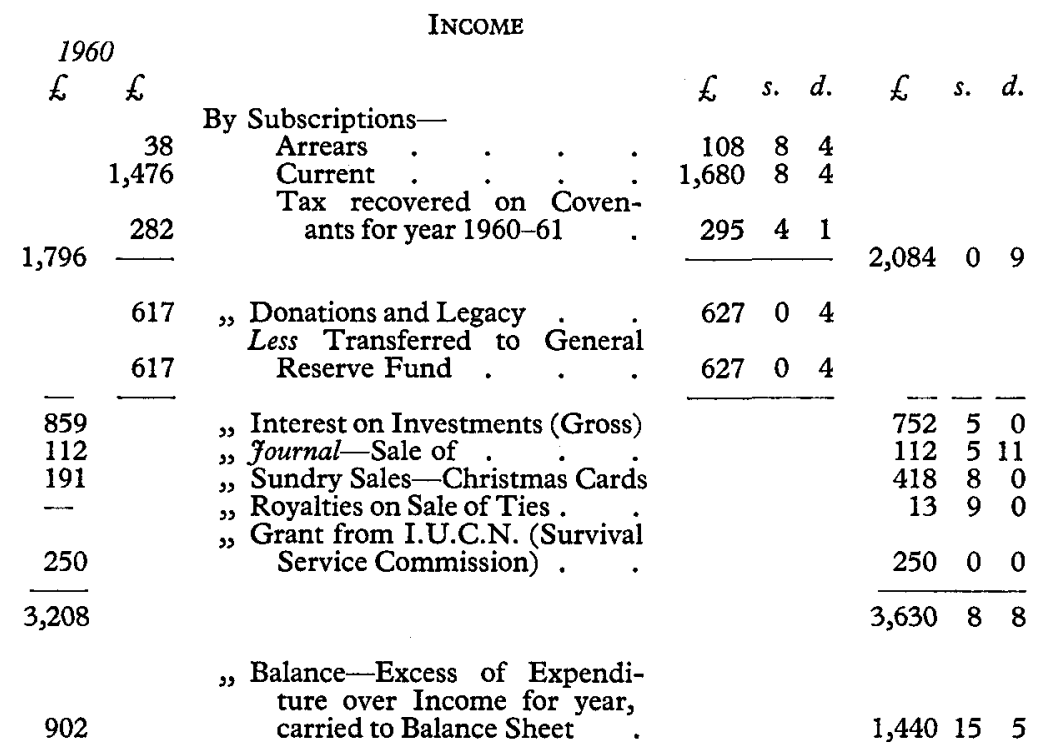




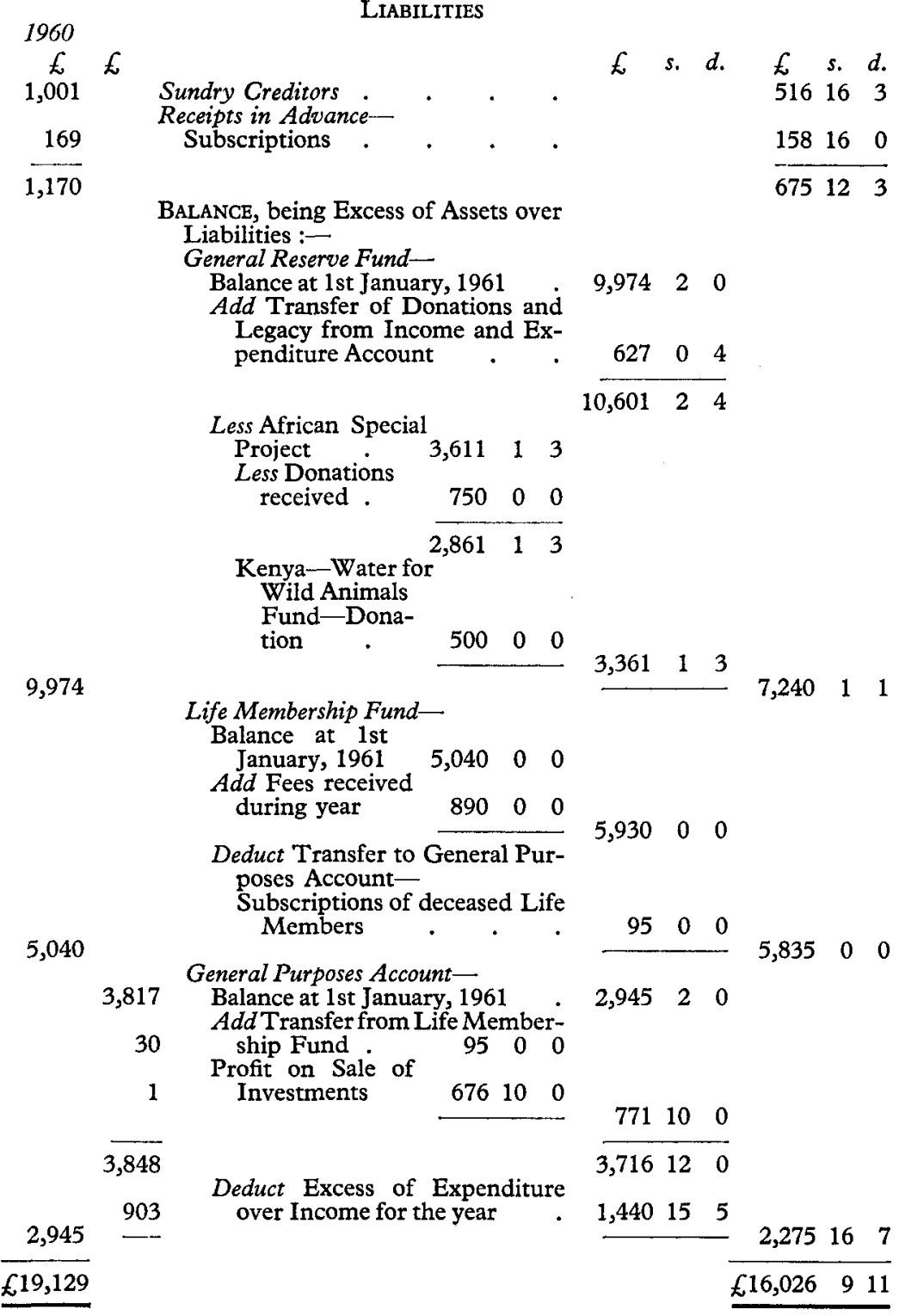


ASSETS

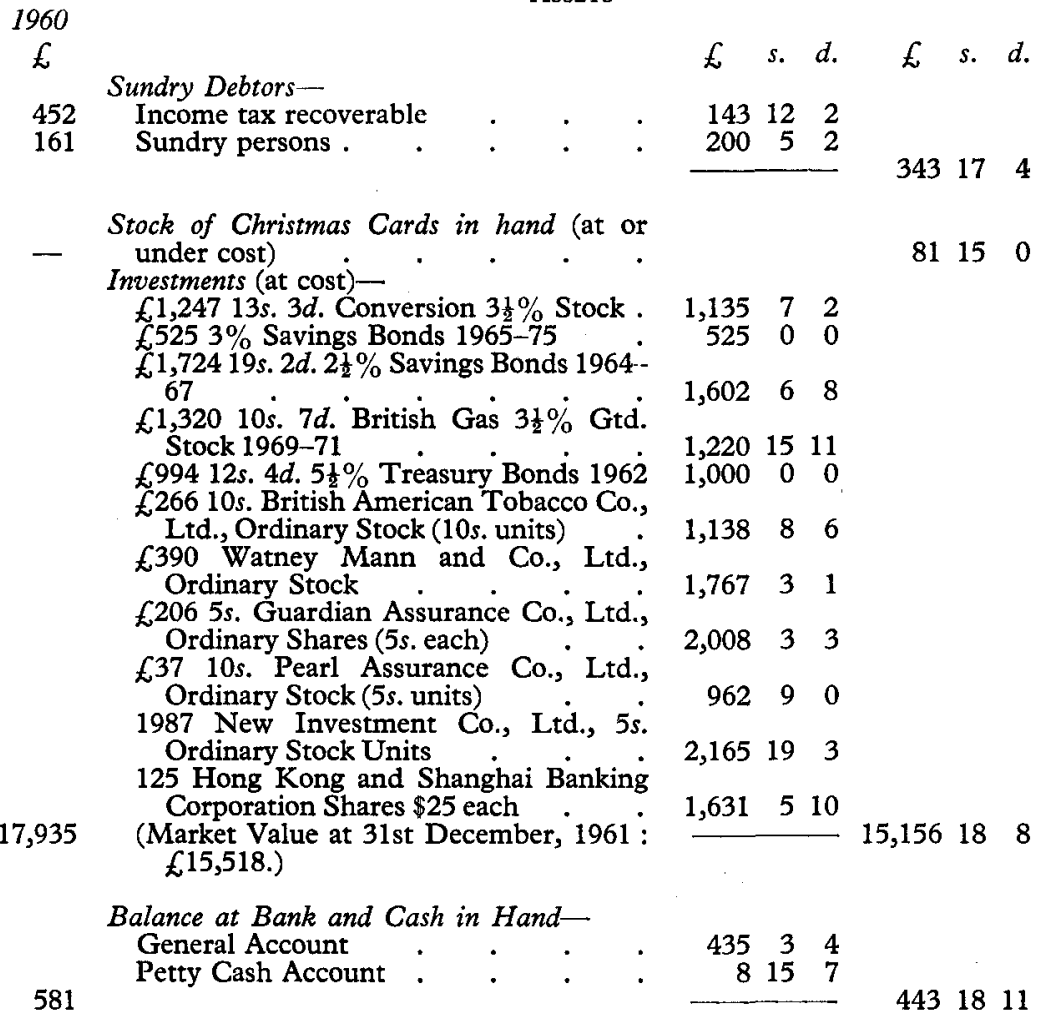

We have examined the above Balance Sheet and the accompanying Income and Expenditure Account with the books and Accounts of the Society and certify them to be in accordance therewith. We have verified the Bank Balance and the Investments of the various Funds.

FinsBuRY Circus House,

BlOMfield Street, LoNdon, E.C. 2.

W. B. KEEN \& CO., Chartered Accountants. 